\title{
Effects of pre-harvest gibberellic acid spraying on gene transcript accumulation during peach fruit development
}

\author{
Camila Pegoraro · Fábio Clasen Chaves • \\ Joceani Dal Cero · César Luís Girardi • \\ Cesar Valmor Rombaldi
}

Received: 9 August 2010/Accepted: 16 March 2011/Published online: 31 March 2011

(C) Springer Science+Business Media B.V. 2011

\begin{abstract}
In order to understand early molecular events associated with increase in fruit size and woolliness prevention induced by pre-harvest gibberellic acid $\left(\mathrm{GA}_{3}\right)$ spraying, differential transcript accumulation of genes encoding proteins putatively involved in protein folding and protection, cell wall metabolism, and endomembrane transport was studied during fruit development of 'Chiripá' peach. Woolliness occurrence reached $100 \%$ in untreated peach, was reduced by $15 \%$ with $\mathrm{GA}_{3}$ spraying at the end of the pit hardening stage and was significantly reduced (by $78 \%$ ) in peaches treated at the beginning of the pit hardening stage despite a significantly increased fruit size. Low incidence of woolliness after cold storage and fruit size increase in early $\mathrm{GA}_{3}$ treated peach was correlated with high transcript accumulation of genes encoding proteins putatively involved in protein folding, and protection of the endoplasmic reticulum (heat shock proteins- $H S P 40$ er) and chloroplast (HSP17.8 ch), endomembrane transport (GTPase), as well as genes involved in cell wall loosening (expansins-Exp1, Exp2, Exp3, Exp4).
\end{abstract}

Keywords Prunus persica Cold storage · Chilling injury $\cdot$ Woolliness $\cdot \mathrm{GA}_{3}$

C. Pegoraro · F. C. Chaves $(\bowtie)$ - J. Dal Cero · C. V. Rombaldi UFPel/FAEM, Department Ciência e Tecnologia Agroindustrial, C.P. 354, Pelotas, RS 90010-900, Brazil

e-mail: chavesfc@gmail.com

C. L. Girardi

Embrapa, Uva e Vinho, Bento Gonçalves,

RS 95700-000, Brazil

\section{Introduction}

White melting flesh peach [Prunus persica (L.) Batsch] such as cultivar Chiripá grown in Southern Brazil show an initial loss of firmness during ripening (Pegoraro et al. 2010a), thus requiring cold storage (CS) to slow down metabolism and prolong shelf-life. However, cold storage can cause severe chilling injuries. Woolliness is one of the most significant imbalances caused by CS, occurring in almost all melting flesh cultivars of peach and nectarine [Prunus persica (L.) Batsch var. nucipersica (Suckow) C. K. Schneid], and imposes serious limitations on marketability (Girardi et al. 2005; Lurie and Crisosto 2005). Woolliness symptoms, characterized by reduced flesh succulence, develop upon removal from cold storage, and the observed dry texture is not a result of reduced water content but due to water being trapped by cell wall pectins (Brummell et al. 2004).

Gibberellic acid $\left(\mathrm{GA}_{3}\right)$ has been shown to delay maturation of peach (Amarante et al. 2005; Ju et al. 1999; Martínez-Romero et al. 2000) and other fruit (Ben-Arie et al. 1996; Ferri et al. 2004; Zilkah et al. 1997) and in some cases, has also been associated with the prevention of chilling injuries (Amarante et al. 2005; Lurie and Crisosto 2005; Pegoraro et al. 2010b). The mechanism of $\mathrm{GA}_{3}$ action seems to vary according with the species involved. For example, Thomas et al. (2005) noticed that gibberellins induce hydrolytic cell wall enzymes and enhance polysaccharide solubilization, favoring cell expansion. $\mathrm{GA}_{3}$ can also regulate genes involved in its own biosynthetic pathway or play a role in the protection of the endomembrane system, and cell wall loosening (Hu et al. 2008). In other cases, $\mathrm{GA}_{3}$ delays the onset of climacteric respiration (Ben-Arie et al. 1996) and ripening cycle (Ferri et al. 2004). In a previous study, effective $\mathrm{GA}_{3}$ prevention of 
woolliness was associated with differential protein and transcript accumulation of cell wall metabolism, endomembrane transport, heat shock proteins, and ethylene biosynthesis observed during room temperature ripening of cold stored 'Chiripá' peach (Pegoraro et al. 2010b). Genes encoding proteins acting on cell wall metabolism and endomembrane transport are potentially involved in the ripening process. Changes in the expression pattern of these genes caused by various stresses, particularly cold stress contribute to woolliness development (González-Agüero et al. 2008; Trainotti et al. 2003, 2006; Girardi et al. 2005). Genes representing physiological cell functions such as cell homeostasis, intracellular transport and cell wall metabolism were chosen based on putative roles identified from previous studies. For example, woolliness has been shown to be associated with imbalanced activities of enzymes associated with cell wall metabolism, endomembrane transport and cellular homeostasis (Brummell et al. 2004; Lurie and Crisosto 2005; González-Agüero et al. 2008; Sun et al. 2010).

In the current study, differential transcript accumulation of genes encoding proteins putatively involved in protein folding and protection, cell wall metabolism and endomembrane transport was studied during fruit development of 'Chiripá' peach in order to understand early molecular events associated with increase in fruit size and woolliness prevention induced by pre-harvest gibberellic acid $\left(\mathrm{GA}_{3}\right)$ spraying.

\section{Materials and methods}

Three replicates of ten trees from a 6-year-old commercial peach orchard, cultivar Chiripá [Prunus persica (L.) Batsch], from Farroupilha, RS, Brazil, were selected based on size uniformity and treated as follows: Control-without $\mathrm{GA}_{3}$ application; T1-sprayed with $4001 \mathrm{ha}^{-1}$ of a $\mathrm{GA}_{3}$ solution $\left(50 \mathrm{mg} \mathrm{l}^{-1} \mathrm{GA}_{3}\right.$ Proggib $^{\circledR}$ and surfactant Silwet $\left.{ }^{\circledR} 0.05 \% \mathrm{v} / \mathrm{v} ; \mathrm{pH} 4.5\right)$ at the beginning of the pit hardening stage (45 days after anthesis, DAA), just after thinning; T2 - sprayed with $4001 \mathrm{ha}^{-1}$ of the $\mathrm{GA}_{3}$ solution at the end of the pit hardening stage (75 DAA). Fruit circumference ( 30 trees per treatment $\times 10$ fruit per tree) was measured weekly alongside the equatorial region starting at 7 days after the full bloom stage until harvest. Samples from 45 DAA until 89 DAA (3 reps; 5 fruit per rep) collected for mRNA analysis were immediately frozen in liquid nitrogen and stored at $-80^{\circ} \mathrm{C}$. Eighty-four kilograms of peaches (12 boxes with $7 \mathrm{~kg}$ of fruit each) were harvested per treatment when fruit color was light green, corresponding to the S3 pre-climacteric stage (Trainotti et al. 2003). Fruit were evaluated for size (circumference), weight, skin color (measured with a Minolta CR-300 colorimeter and expressed in hue values), reddish color, flesh firmness, soluble solids content (SSC), L-ascorbic acid content and ethylene production. Fruit were then cold stored at $1.0 \pm 1.0^{\circ} \mathrm{C}, 92 \pm 5 \%$ relative humidity $(\mathrm{RH})$ for 30 days followed by ripening at $23 \pm 3^{\circ} \mathrm{C}$ and $75 \pm 5 \%$ $\mathrm{RH}$ for 2 days. Upon the 2 day ripening, fruit were evaluated for woolliness incidence. Those fruit that upon hand squeezing did not release any juice were considered woolly (Girardi et al. 2005). Reddish color was visually assessed, following common practice, attributing values 1, 2, 3 or 4 to fruit with less than $25 \%, 25$ to $50 \%, 51$ to $75 \%$ and more than $75 \%$ of reddish surface respectively. The experiments were performed in a completely randomized design. Percentage data was normalized according to the equation $\mathrm{f}(\mathrm{x})=\operatorname{arcsine} \sqrt{ } X$. ANOVA was performed using the $F$ test at the $5 \%$ significance level. Means of treatments were compared using Duncan's test at the 5\% significance level.

RNA was extracted from $0.1 \mathrm{~g}$ of peach flesh following the protocol described for PureLinK ${ }^{\mathrm{TM}}$ reagent (Plant RNA Reagent-Invitrogen ${ }^{\mathrm{TM}}$ ) and then treated with DNAse I-Invitrogen ${ }^{\mathrm{TM}}$. The quantity and quality of the RNA was assessed spectroscopically, by electrophoresis in agarose gel, and PCR. cDNAs were obtained from $2 \mu \mathrm{g}$ of RNA using the commercial kit SuperScript First-Strand System for RT-PCR (Invitrogen ${ }^{\mathrm{TM}}$ ) and cDNA quality was confirmed by PCR.

Gene-specific primers were designed from sequences deposited in GenBank using Vector NTI Advance ${ }^{\mathrm{TM}} 10$ (Invitrogen $^{\mathrm{TM}}$ ). The criteria used for primer selection consisted of: amplicon size between 100 and 150 bp, CG content between 40 and $60 \%, 3^{\prime}$ ends with less than two $\mathrm{C}$ and $\mathrm{G}$ bases in the last five nucleotides, and melting temperature ranging from 60 to $65^{\circ} \mathrm{C}$ according to Applied Biosystems ${ }^{\circledR}$ recommendations. The sizes of amplification products and their specificity were tested in agarose gels $(2 \% \mathrm{w} / \mathrm{v})$ prior to q-PCR. Melting curves were evaluated and only primers giving single peaks and amplification efficiency close to $100 \%$ were used (Table 1). q-PCR was performed in a 7500 Real-Time PCR system (Applied Biosystems ${ }^{\circledR}$ ) using a fluorescent dye SYBR ${ }^{\circledR}$ Green. The amplification reaction was carried out in a total volume of $25 \mu \mathrm{l}$, containing $2 \mu \mathrm{M}$ of each primer, $12.5 \mu \mathrm{l}$ of PCR Master Mix SYBR ${ }^{\circledR}$ Green, $1 \mu$ of cDNA (diluted fivefold), and water to make up the final volume. Samples were loaded in 96 well optic plates (Applied Biosystems ${ }^{\circledR}$ ) and covered with optic adhesives (Applied Biosystems ${ }^{\circledR}$ ). Thermal cycle conditions were as follows: denaturing at $50^{\circ} \mathrm{C}$ for $2 \mathrm{~min}$ and $95^{\circ} \mathrm{C}$ for $10 \mathrm{~min}$, followed by 40 threestep cycles $\left(95^{\circ} \mathrm{C}\right.$ for $30 \mathrm{~s}, 57^{\circ} \mathrm{C}$ for $1 \mathrm{~min}$, and $72^{\circ} \mathrm{C}$ for $1 \mathrm{~min}$ ) and final extension at $72^{\circ} \mathrm{C}$ for $5 \mathrm{~min}$. Relative quantification of each single gene expression was performed using the comparative threshold cycle method, as 
Table 1 List of specific primers used for quantitative PCR analysis of candidate genes

\begin{tabular}{|c|c|c|c|}
\hline Genes & GI & Forward & Reverse \\
\hline \multicolumn{4}{|l|}{ Cell wall metabolism } \\
\hline Expansin $1($ Expl) & 16305104 & AAACGTTGGTGGTGCCGGTGAT & TTGCTTGCCAACCAGTCCTGGA \\
\hline $\operatorname{Exp} 2$ & 29466640 & TCCAGGACTGGTTGGCAAGCAA & TAGGACACCACTGTGCGGCCAT \\
\hline Exp3 & 29466642 & GGGTGCATGGGAAGCAGCTCAT & CCATGGTGCCAGAGGCATCAGA \\
\hline Exp4 & 21901947 & TGAGCTGTGGGGCATGCTATGA & AGGATCACACCAGCCACCTGGT \\
\hline Pectin methylesterase $(P M E)$ & 1213628 & AGGTGGCCTCCATTCTCTCTCAGTT & GGGAAGCAGAGAGAGACCAGTTCAA \\
\hline Endopolygalacturonase $(P G)$ & 110293962 & AAAGGGTGCCCTGGTCAGGTAAGATA & GCTCTTCTAGGTGGAAGCCCAAGAAA \\
\hline Pectate lyase $(P L)$ & 22483439 & GCCTTGCCGTACGCTCATGTC & CTTCAGCСТCAАССССТTСССТ \\
\hline Endo-1,4-beta-mannosidase ( $\beta$-Man $)$ & 157313309 & ACAAGGTTTTCCCATCCATGTTGAA & ATGGGTCAGAAGCCACATACATCAA \\
\hline \multicolumn{4}{|l|}{ Endomembrane transport } \\
\hline GTPase & 145361083 & CGTGAAACGTTCGAAGGCCATT & TCTCCTTAACGCCGATGGTCGT \\
\hline \multicolumn{4}{|l|}{ Heat shock proteins (HSP) } \\
\hline $\begin{array}{l}\text { HSP70 endoplasmic reticulum } \\
\text { resident }(H S P 70 \text { er })\end{array}$ & 240254046 & CCGCGGTCCAAGGTGGAGTATT & TCAAAGGCGCAACATCAAGCAG \\
\hline HSP40 er & 79318135 & CGCCAGCAGCTTCTGCACACAA & TTCTCCGTCGAGCCACGCAAAT \\
\hline $\begin{array}{l}\text { HSP17.8 chloroplast resident } \\
(H S P 17.8 \mathrm{ch})\end{array}$ & 30680121 & CCGAGTCACCAGCTTTGCTCAGAA & TGTTGTTGCCGAAGAAGCTTGGAA \\
\hline HSP70 ch & 145359060 & CCAACCTCCGCCTTCCTTCGTA & ACCAACGGTGTATCGGGAAGCG \\
\hline $\begin{array}{l}\text { HSP60 mitochondria resident } \\
(\text { HSP60 mi) }\end{array}$ & 20466255 & ACCTCGCCTCCAAGGCAAGGAT & TTCTGCTGGAAACCTGGCGAGC \\
\hline \multicolumn{4}{|l|}{ Endogenous control } \\
\hline $18 S$ & 66627320 & AAAACGACTCTCGGCAACGGATA & ATGGTTCACGGGATTCTGCAATT \\
\hline
\end{tabular}

described by Livak and Schmittgen (2001). For each cDNA, $18 S$ was used as a reference gene to quantify cDNA abundance (at the same dilution as mentioned above). Threshold cycle (CT) was calculated based on the PCR exponential reaction obtained from the relative expression level (REL) formula, $\mathrm{REL}=2^{-\Delta \Delta \mathrm{CT}}$. Results were expressed as relative mRNA abundance in a color diagram using the Multi Experiment Viewer (TIGR MeV) software (Saeed et al. 2003). mRNA abundance of each gene from Control fruit at 45 DAA served as the baseline for determining relative transcript accumulation.

\section{Results and discussion}

Fruit in all treatments had similar growth rates until approximately 80 days after anthesis when fruit sprayed with $\mathrm{GA}_{3}$ at the beginning of pit hardening (T1) started growing faster than peach treated with $\mathrm{GA}_{3}$ at the end of pit hardening (T2), and faster than Control peach not sprayed with $\mathrm{GA}_{3}$ (Fig. 1). Possibly because prior to pit hardening cell division and expansion are occurring, while after pit hardening only expansion occurs. In general, the growth curves showed a sigmoidal pattern commonly observed in peach, plum and nectarine (Lurie and Crisosto 2005; Trainotti et al. 2003, 2006). These physiological responses

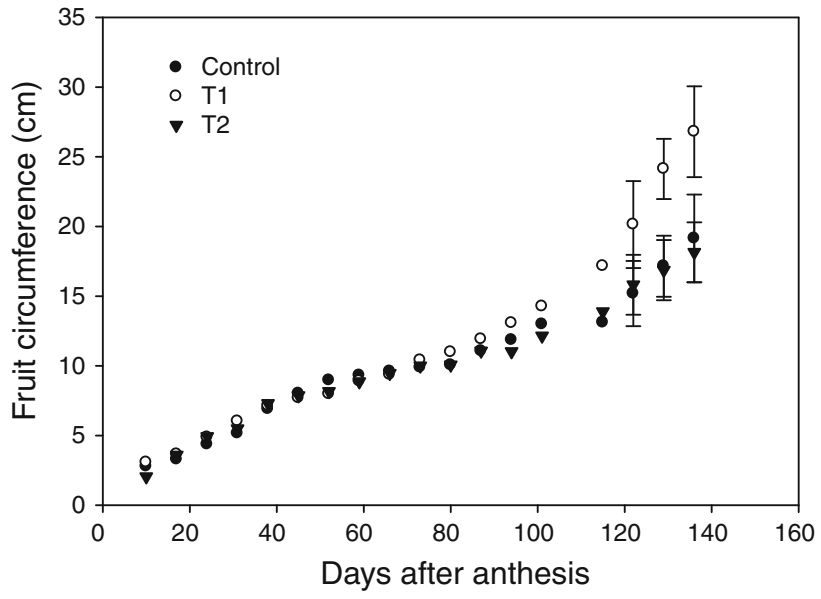

Fig. 1 Growth curves of Control and $\mathrm{GA}_{3}$ treated Chiripá peaches at the beginning (T1), and end of the pit hardening (T2) stages (Error bars represent standard deviation of the mean)

are consistent with the findings of Arnaud et al. (2010) who observed that gibberellins act degrading DELLA proteins via MAP kinases, allowing for transcription factors to bind to gene promoters, regulating expression of genes involved in the cell cycle and cell wall metabolism. Cell wall biosynthesis and cell division are both processes that have to be activated to induce fruit growth and most genes involved in these processes are $\mathrm{GA}_{3}$-inducible (Vriesen 
Table 2 Physicochemical characteristics at harvest of Control and $\mathrm{GA}_{3}$ treated Chiripá peaches at the beginning (T1), and end of pit hardening (T2) stages, and wooliness occurrence after 30 days of cold storage followed by 2 days of ripening at room temperature

\begin{tabular}{lllllllr}
\hline Treatment & $\begin{array}{l}\text { Circumference } \\
(\mathrm{cm})\end{array}$ & $\begin{array}{l}\text { Reddish color } \\
(1-4)\end{array}$ & $\begin{array}{l}\text { Hue } \\
\text { angle }\end{array}$ & $\begin{array}{l}\text { Soluble solids } \\
(\text { Brix })\end{array}$ & $\begin{array}{l}\text { L-ascorbic acid } \\
\left(\mathrm{mg} 100 \mathrm{~g}^{-1}\right)\end{array}$ & $\begin{array}{l}\text { Ethylene } \\
\left(\mathrm{nL} \mathrm{g}^{-1} \mathrm{~h}^{-1}\right)\end{array}$ & $\begin{array}{l}\text { Woolliness } \\
(\%)\end{array}$ \\
\hline Control & $20.31 \mathrm{~b}^{*}$ & 2 & $96 \mathrm{a}$ & $12.3 \mathrm{a}$ & $2.69 \mathrm{a}$ & $0.69 \mathrm{a}$ & $100 \mathrm{a}$ \\
T1 & $27.14 \mathrm{a}$ & 2 & $102 \mathrm{a}$ & $12.8 \mathrm{a}$ & $2.85 \mathrm{a}$ & $0.76 \mathrm{a}$ & $22 \mathrm{c}$ \\
$\mathrm{T} 2$ & $21.14 \mathrm{~b}$ & 2 & $99 \mathrm{a}$ & $12.9 \mathrm{a}$ & $3.01 \mathrm{a}$ & $0.65 \mathrm{a}$ & $85 \mathrm{~b}$ \\
\hline
\end{tabular}

* Means of treatment followed by different letters are statistically different according to Duncan's test $(P \leq 0.05)$

et al. 2008). This could explain the increment in fruit size when $\mathrm{GA}_{3}$ was sprayed at the beginning of the pit hardening stage, when growth is characterized by high cell division (Trainotti et al. 2003, 2006).

Pre-harvest spraying of $\mathrm{GA}_{3}$ at the beginning of pit hardening stage (T1) resulted in an increase in fruit size compared to the untreated fruit (Control) (Table 2). Delaying $\mathrm{GA}_{3}$ application until the end of pit hardening stage (T2) did not contribute to an increase in size. Positive effects of $\mathrm{GA}_{3}$ application on fruit size have already been mentioned in the literature (Amarante et al. 2005; Ju et al. 1999; Pegoraro et al. 2010b; Zhang et al. 2008). However, in some cases fruit size increase is a consequence of delayed fruit ripening (Lurie and Crisosto 2005). In 'Chiripá' peach, for instance, the size increase occurred without delaying ripening, since fruit in all treatments were harvested on the same date, at pre-climacteric ripening stage, and produced low levels of ethylene ranging from 0.65 to $0.76 \mathrm{~nL} \mathrm{~g}^{-1} \mathrm{~h}^{-1}$. Flesh firmness, soluble solids and L-ascorbic acid content did not vary among treatments (Table 2).

As previously observed by Girardi et al. (2005), woolliness incidence was high in Control fruit not sprayed with $\mathrm{GA}_{3}$, reaching $100 \%$ after 30 days of cold storage and 2 days of ripening at $23^{\circ} \mathrm{C} \pm 3^{\circ} \mathrm{C}$ and $75 \pm 5 \% \mathrm{RH}$ (Table 2). Similarly, T2 fruit treated with $\mathrm{GA}_{3}$ at the end of the pit hardening showed a small reduction in woolliness incidence, totaling $85 \%$ of woolly fruit after 2 days of ripening. However, fruit that received $\mathrm{GA}_{3}$ treatment at the beginning of pit hardening (T1) had the lowest woolliness incidence (22\%), which was in agreement with citations by Lurie and Crisosto (2005) that mentioned the contribution of gibberellins to the prevention of chilling injuries (CI). Similarly, Amarante et al. (2005) found lower incidence of $\mathrm{CI}$ in 'Rubidoux' peach treated with $\mathrm{GA}_{3}$ and stored for 30 days under CS. Although knowledge of the molecular basis for this behavior is still incomplete, some relationships between $\mathrm{GA}_{3}$ action and the expression of genes codifying proteins involved in cellular homeostasis (Pegoraro et al. 2010b), cell division and expansion (Arnaud et al. 2010; Vriesen et al. 2008) and cell wall metabolism (Brummell et al. 2004) have been identified.
In order to understand the molecular mechanisms involved in the fruit size increase and woolliness reduction induced by $\mathrm{GA}_{3}$ treatment, a set of 14 genes associated with cell wall metabolism (8), endomembrane transport (1) and protein folding and protection (5) were analyzed (Table 1). During a normal ripening process the increase in mRNA, protein abundance, and activity of cell wall hydrolases has been observed (Girardi et al. 2005; González-Agüero et al. 2008; Lurie and Crisosto 2005; Pegoraro et al. 2010b; Trainotti et al. 2003, 2006). In addition, to the activation of genes associated with intracellular transport and cell homeostasis (González-Agüero et al. 2008; Pegoraro et al. 2010b). Based on these observations and considering the $\mathrm{GA}_{3}$ effect on cell wall metabolism (Ben-Arie et al. 1996), emerged the hypothesis that this plant hormone could affect cell division at early stages (beginning of pit hardening) of fruit development. Fruit size increase is possibly a result of greater cell division and elongation (Ozga and Dennis 2003), which require the action of expansins (Choi et al. 2006) and hydrolytic enzymes acting on cell wall components (Thomas et al. 2005). Moreover, there must be a coordinated action between synthesis and transport of these proteins by the endomembrane system, as well as the metabolism and biogenesis of chloroplasts and mitochondria.

Treatments that lead to higher incidence of woolliness after cold storage (Control and T2) had transcript accumulation of cell wall metabolism genes (Exp1, Exp3, Exp4, $P M E, P L$ and $\beta$-Man) varying less than threefold from 45 DAA through 89 DAA. Similar limited variation in transcript accumulation was observed for genes encoding chaperone proteins (HSP70 er, HSP40 er, HSP17.8 ch, $H S P 70 \mathrm{ch}$, and HSP6O $\mathrm{mi}$ ) and the GTPase associated to the endomembrane transport. Higher transcript accumulation was seen for $P G$ in Control fruit from 75 DAA to 89 DAA and for Exp2 in T2 fruit at 89 DAA. In T1 peach, which developed into larger fruit and had low woolliness incidence, transcript accumulation of cell wall metabolism associated genes (Exp4, PME, PL and $\beta$-Man) did not vary more than threefold from 45 DAA to 89 DAA. A similar pattern was observed for genes encoding chaperone proteins (HSP70 er, HSP70 ch, and HSP60 mi). However, 
genes encoding Expl, Exp2, and Exp3, HSP40 er, HSP $17.8 \mathrm{ch}$ and GTPase had a 50 fold increase in transcript accumulation from 75 DAA to 89 DAA. In addition, the endopolygalacturonase gene known for its transcriptional (González-Agüero et al. 2008; Pegoraro et al. 2010a) and post-transcriptional expression during peach ripening (Girardi et al. 2005; Pegoraro et al. 2010b), except for a peak in transcript accumulation at 75 DAA, had lower transcript abundance when compared to control fruit.

$\mathrm{GA}_{3}$ application at the beginning of pit hardening induced an early expression (during growth 52 DAA until 89 DAA) of genes associated with cell wall metabolism and cell homeostasis (Fig. 2) and similar induced expression was observed in fully ripe fruit (Pegoraro et al. 2010b). Obenland et al. (2003) also observed a positive correlation between Expl mRNA and protein expression and normal ripening evolution, and woolliness prevention. Exp1, Exp2, Exp3, and Exp4 were highly expressed during pear ripening, but only Expl was detected at an early stage of fruit development (Hiwasa et al. 2003). In Chiripá peach, $\mathrm{GA}_{3}$ was able to induce $\operatorname{Exp} 1, \operatorname{Exp} 2$, and $\operatorname{Exp} 3$, and Exp4 (to a lower extent), at early stages of peach development before the onset of ripening. Different members of the multigene family of expansins were chosen because previous studies demonstrated that these proteins act differently according to species, tissue and developmental stage, and are also differentially regulated by hormonal, and environmental signals (Brummell et al. 1999; Harrison et al. 2001; Thomas et al. 2005; Vriesen et al. 2008). In addition, expansin genes were possibly originated by duplication events (Hittinger and Carroll 2007), leading to distinct functions. Alternatively, gene duplicates can undergo simultaneous reduction of their activity thereby maintaining the total capacity of the ancestral gene (Gallego-Bartolomé et al. 2010), this is the case of expansins that have the same function.

The main changes occurring during fruit development are mediated by proteins transported through the cell endomembrane system and organelles, or secreted to the apoplast, indicating that GTPase is associated with development and if inhibited can cause physiologic disturbances (Abbal et al. 2008). The higher expression of GTPase induced by $\mathrm{GA}_{3}$ in woolliness free peaches is another evidence for the involvement the endomembrane trafficking favoring transport and recycling of proteins associated with cell wall and organelle biogenesis (González-Agüero et al. 2008). GA 3 induced transcript accumulation of this gene possibly favored the transport of proteins and enzymes responsible for cell wall solubilization, leading to greater cell division and/or expansion resulting in increase in fruit size. $\mathrm{Hu}$ et al. (2008) have shown that gibberellins induce stem elongation and increase transcription levels of several genes encoding proteins involved in cell wall loosening, such as expansins. $\mathrm{GA}_{3}$ application may have also induced auxin synthesis, responsible for acidifying the cell wall which enables the action of pH-dependent expansins (Choi et al. 2006; Xie et al. 2009). Jackson (1968) had previously observed that in some apricots and peach varieties a high gibberellin concentration is needed at the beginning of the growth curve to induce cell division and later in development in order to achieve cell expansion.

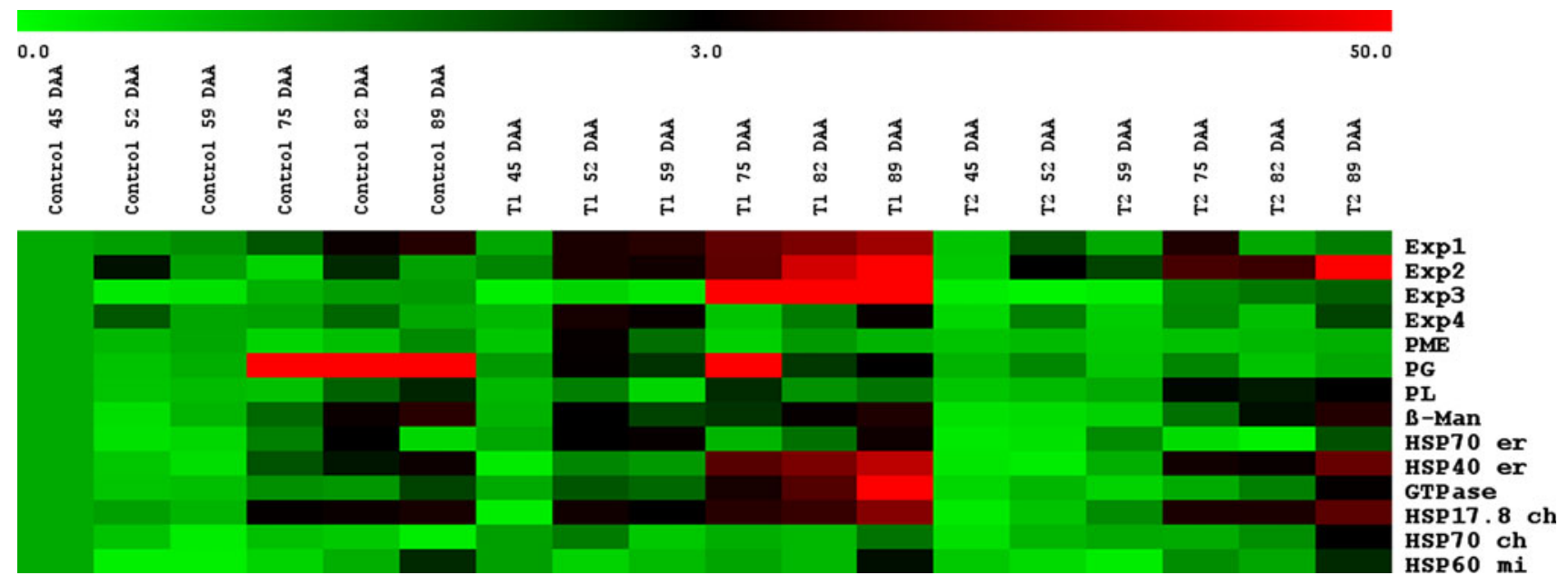

Fig. 2 Relative gene transcript accumulation in Control, $\mathrm{GA}_{3}$ treated 'Chiripá' peaches at the beginning (T1), and end of pit hardening (T2) during fruit development at 45, 52, 59, 75, 82, and 89 days after anthesis (DAA). * mRNA abundance is represented, on a scale of 0-50, using the Multi Experiment Viewer (TIGR MeV) software. The lower end of the scale (light green color) indicates the lowest level; black color represents accumulation 3 times higher than the light green end; and red color in the upper end of the scale represents the highest mRNA abundance, 50 times higher than the lowest. mRNA abundance of each gene from Control 45 DAA fruit served as the baseline for determining relative RNA levels. (Color figure online) 
In summary, supplying $\mathrm{GA}_{3}$ at the beginning of pit hardening induced transcript accumulation of genes encoding proteins putatively involved in protein folding and protection of the endoplasmic reticulum (HSP4O er) and chloroplast (HSP17.8 ch), endomembrane transport (GTPase), as well as genes involved in cell wall loosening (Exp1, Exp2, Exp3, Exp4), contributing to the mechanism responsible for increased fruit size and prevention of woolliness after cold storage. Suggesting woolliness incidence reduction is likely influenced by up-regulation of genes encoding proteins associated with the maintenance of cell homeostasis and endomembrane transport under stress conditions, and up-regulation of genes encoding proteins associated with cell wall loosening.

Acknowledgments To Professor Antônio Costa Oliveira for his help with qPCR analyses and to CAPES and CNPq for financial support.

\section{References}

Abbal P, Pradal M, Muniz L, Sauvage F-X, Chatelet P, Ueda T, Tesniere C (2008) Molecular characterization and expression analysis of the Rab GTPase family in Vitis vinifera reveal the specific expression of a VvRabA protein. J Exp Bot 59:2403-2416

Amarante CVT, Drehmer AMF, Souza F, Francescato P (2005) Preharvest spraying with gibberellic acid $\left(\mathrm{GA}_{3}\right)$ and aminoethoxyvinilglycine (AVG) delays fruit maturity and reduces fruit losses on peaches. Revista Brasileira de Fruticultura 27:1-5

Arnaud N, Girin T, Sorefan K, Fuentes S, Wood TA, Lawrenson T, Sablowski R, Ostergaard L (2010) Gibberellins control fruit patterning in Arabidopsis thaliana. Genes Dev 24:2127-2132

Ben-Arie R, Saks Y, Sonego L, Frank A (1996) Cell wall metabolism in gibberellin-treated persimmon fruits. Plant Growth Regul 19:25-33

Brummell DA, Harpster MH, Dunsmuir P (1999) Differential expression of expansin gene family members during growth and ripening of tomato fruit. Plant Mol Biol 39:161-169

Brummell DA, Dal Cin V, Lurie S, Crisosto CH, Labavitch JM (2004) Cell wall metabolism during the development of chilling injury in cold-stored peach fruit: association of mealiness with arrested disassembly of cell wall pectins. J Exp Bot 55:2041-2052

Choi D, Cho H-T, Lee Y (2006) Expansins: expanding importance in plant growth and development. Physiol Plant 126:511-518

Ferri VC, Rinaldi MM, Silva JA, Luchetta L, Marini L, Rombaldi CV (2004) Gibberellic acid on ripening delay of Kakis (Diospyrus kaki L.) cultivar Fuyu. Ciência e Tecnologia de Alimentos $24: 1-5$

Gallego-Bartolomé J, Minguet EG, Marín JA, Prat S, Blázquez MA, Alabadí D (2010) Transcriptional diversification and functional conservation between DELLA proteins in Arabidopsis. Mol Biol Evol 27:1247-1256

Girardi CL, Corrent AR, Lucchetta L, Zanuzo MR, Da Costa TS, Brackmann A, Twyman RM, Nora FR, Nora L, Silva JA, Rombaldi CV (2005) Effect of ethylene, intermittent warming and controlled atmosphere on postharvest quality and the occurrence of woolliness in peach (Prunus persica cv. Chiripa) during cold storage. Postharvest Biol Technol 38:25-33
González-Agüero M, Pavez L, Ibánez F, Pacheco I, Campos-Vargas R, Meisel LA, Orellana A, Retamales J, Silva H, González M, Cambiazo V (2008) Identification of woolliness response genes in peach fruit after post-harvest treatments. J Exp Bot 59:1973-1986

Harrison EP, McQueen-Mason SJ, Manning K (2001) Expression of six expansin genes in relation to extension activity in developing strawberry fruit. J Exp Bot 52:1437-1446

Hittinger CT, Carroll SB (2007) Gene duplication and the adaptive evolution of a classic genetic switch. Nature 449:677-681

Hiwasa K, Rose JKC, Nakano R, Inaba A, Kubo Y (2003) Differential expression of seven $\alpha$-expansin genes during growth and ripening of pear fruit. Physiol Plantarum 117:564-572

Hu J, Mitchum MG, Barnaby N, Ayele BT, Ogawa M, Nam E, Lai W-C, Hanada A, Alonso JM, Ecker JR, Swain SM, Yamaguchi S, Kamiya Y, Sun T-P (2008) Potential sites of bioactive gibberellin production during reproductive growth in Arabidopsis. Plant Cell 20:320-336

Jackson DI (1968) Gibberellin and the growth of peach and apricot fruits. Aust J Biol Sci 21:209-216

Ju Z, Duan Y, Ju Z (1999) Combinations of GA(3) and AVG delay fruit maturation, increase fruit size and improve storage life of 'Feicheng' peaches. J Hort Sci Biotechnol 74:579-583

Livak KJ, Schmittgen TD (2001) Analysis of relative gene expression data using real-time quantitative PCR and the $2^{-\Delta \Delta C T}$ method. Methods 25:402-408

Lurie S, Crisosto CH (2005) Chilling injury in peach and nectarine. Postharvest Biol Technol 37:195-208

Martínez-Romero D, Valero D, Serrano M, Burlo F, Carbonell A, Burgos L, Riquelme F (2000) Exogenous polyamines and gibberellic acid effects on peach (Prunus persica L.) storability improvement. J Food Sci 65:288-294

Obenland DM, Crisosto CH, Rose JKC (2003) Expansin protein levels decline with the development of mealiness in peaches. Postharvest Biol Technol 29:11-18

Ozga J, Dennis M (2003) Hormonal interactions in fruit development. J Plant Growth Regul 22:73-81

Pegoraro C, Manica-Berto R, Chaves FC, Borges CT, Franco JJ, Rombaldi CV, Silva JA (2010a) Differential expression of genes associated with endomembrane transport and cell wall metabolism during ripening of 'Chimarrita' and 'Granada' peach. Hort Environ Biotechnol 51:207-211

Pegoraro C, Zanuzo MR, Chaves FC, Brackmann A, Girardi CL, Lucchetta L, Nora L, Silva JA, Rombaldi CV (2010b) Physiological and molecular changes associated with prevention of woolliness in peach following pre-harvest application of gibberellic acid. Postharvest Biol Technol 57:19-26

Saeed AI, Sharov V, White J, Li J, Liang W, Bhagabati N, Brainsted J, Klapa M, Currier T, Thiagarajan M, Sturn A, Snuffin M, Rezantsev A, Popov D, Ryltsov A, Kostukovich E, Borisovski I, Liu Z, Vinsavichi A, Trush V, Quackenbusch J (2003) TM4: a free, open-source system for microarray data management and analysis. Biotechniques 34:374-378

Sun J-H, Chen J-Y, Kuang J-F, Chen W-X, Lu W-J (2010) Expression of sHSP genes was affected by heat shock and cold acclimation in relation to chilling tolerance in plum fruit. Postharvest Biol Technol 55:91-96

Thomas SG, Rieu I, Steber CM (2005) Gibberellin metabolism and signaling. Vitam Horm 7:289-338

Trainotti L, Zanin D, Casadoro G (2003) A cell wall-oriented genomic approach reveals a new and unexpected complexity of the softening in peaches. J Exp Bot 54:1821-1832

Trainotti L, Bonghi C, Ziliotto F, Zanin D, Rasori A, Casadoro G, Ramina A, Tonutti P (2006) The use of microarray $\mu$ PEACH1.0 to investigate transcriptome changes during transition from 
pre-climacteric to climacteric phase in peach fruit. Plant Sci 170:606-613

Vriesen WH, Feron R, Maretto F, Keijman J, Mariani C (2008) Changes in tomato ovary transcriptome demonstrate complex hormonal regulation of fruit set. New Phytol 177:60-76

Xie H, Chen J, Yuan R, Zhong Y, Feng H, Xu S, Li J, Wang L (2009) Differential expression and regulation of expansin gene family members during fruit growth and development of 'Shija' longan fruit. Plant Growth Regul 58:225-233
Zhang C, Lee U, Tanabe K (2008) Hormonal regulation of fruit set, parthenogenesis induction and fruit expansion in Japanese pear. Plant Growth Regul 55:231-240

Zilkah S, Lurie S, Lapsker Z, Zuthi Y, David I, Yesselson Y, Antman S, Ben-Arie R (1997) The ripening and storage quality of nectarine fruits in response to preharvest application of gibberellic acid. J Hort Sci Biotechnol 72:355-362 